\title{
ASPEK PERKEMBANGAN BAHASA ANAK PADA TINGKAT SEKOLAH DASAR
}

\author{
Rizka Febriyani Awliyah', ,Suyadi', Fina Raudlatul Jannah ${ }^{3}$, Arif Mustofa ${ }^{4}$ \\ FITK PGMI, UIN Sunan Kalijaga Yogyakarta \\ Email: febyawliyah16@gmail.com
}

\begin{abstract}
Language is used as a means for communication and language is an untroduction education. To understand the important information, understand what the teacher and others are communicating, and to be able to communicate better then the child must understand the language. This research is done in order to better understand the development of children's language and the factors that influence it. In this research, researchers used the study literatur method and use a qualitative approach. Books, journals, and reports of past research are the sources of data usedthe results of this study stated that the development of a rapidly increasing language in elementary school level children is development of morphology, syntactic, phoneme, vocabulary, pholonogy, and semantic. With this research is expected to help parents, teacher and prospective teachers to understand the development of the language of elementary school level children.
\end{abstract}

Keyword: development, language, children, elementary school.

Abstrak: Bahasa digunakan sebagai sarana untuk berkomunikasi dan bahasa merupakan sebuah pengantar dalam Pendidikan. Untuk memahami berbagai informasi penting, mengerti dengan apa yang di sampaikan oleh guru dan orang lain, serta untuk dapat berkomunikasi dengan baik maka anak harus memahami bahasa. Penelitian ini dilakukan dengan tujuan untuk lebih memahami perkembangan bahasa anak serta faktor-faktor yang dapat mempengaruhinya. Dalam penelitian ini, peneliti menggunakan metode studi pustaka (literatur) dan menggunakan pendekatan kualitatif. Buku, jurnal, serta laporan hasil penelitian terdahulu merupakan sumber data yang digunakan. Hasil penelitian ini menyatakan bahwa perkembangan bahasa yang meningkat pesat pada anak tingkat sekolah dasar adalah perkembangan morfologi, sintaksis, fonem, kosa kata, fonologi, dan semantik. Dengan adanya kajian ini diharapkan dapat membantu orang tua, guru serta calon guru untuk memahami perkembangan bahasa anak tingkat sekolah dasar.

Kata kunci: perkembangan, bahasa, anak, sekolah dasar.

\section{PENDAHULUAN}

Menurut Yusuf Syamsu (2001) dalam buku (Susanto, 2011:19) kematangan atau kedewasaan yang berlangsung secara berurut, progresif dan berkelanjutan yang dialami oleh individual merupakan salah satu bentuk dari baik menyangkut psikis (rohaniah) dan menyangkut fisik (jasmaniah). Bentuk dari perkembangan dari segi aspek fisik manusia dapat berupa bertambahnya perkembangan tinggi badan, bertambahnya berat badan, serta meningkatnya sistem motorik (otot dan syaraf) dan otak. Bentuk dari perkembangan non-fisik manusia berupa perkembangan dalam kognitif, sosioemosional serta bahasa.

Selaku individual yang sedang mengalami pertambahan atau pertumbuhan maka pada saat prosesnya sangat dipengaruhi oleh perkembangan bahasa. Bahasa menjadi faktor penting dan harus dikuasai oleh manusia. Ungkapan bahasa merupakan sebuah pengantar dalam 
pendidikan tentu tidak terdengar asing untuk mengingatkan kita bagaimana pentingnya kegunaan bahasa dalam kehidupan sehari-hari. Apabila telah fasih dalam menguasi bahasa maka anak tidak akan mengalami kesulitan dalam mendapatkan pesan penting, informasi, dan ungkapan yang diucapkan guru. Menurut (Desiani Natalina, 2019:30) perkembangan bahasa merupakan bentuk dari proses alamiah yang dialami oleh individu dalam memanfaatkan dan menggunakan bahasa dalam beraktivitas. Maka agar perkembangan bahasa bisa berjalan dengan optimal haruslah anak diberikan fasilitas pengembangan berbahasa.

Orang tua dan guru tentu menjadi fasilitas utama dalam perkembangan bahasa anak. Berinteraksi dan berkomunikasi dengan anak sangat berpengaruh dalam perkembangan bahasa, dengan memberikan contoh dalam menggunakan bahasa yang baik dan tepat. Sejalan dengan (Palupi, 2015:32) Memfasilitasi perkembangan bahasa anak, dengan cara orang dewasa menjadi model atau contoh bagi anak untuk mendengarkan, memperluas, dan mengerti tentang bahasa saat sedang berinteraksi.

Dua hal yang tidak dapat di pisahkan satu sama lain yaitu bahasa (language) dan berbicara. Bahasa merupakan bentuk komunikasi yang ditimbulkan oleh pikiran dan perasaan dalam menyampaikan suatu makna atau maksud kepada orang lain. Dalam bahasa tersebut, diperlukan penggunaan simbol atau tanda yang dimasukkan ke dalam sebuah tata bahasa yang berada dalam struktur aturan tertentu. Apabila anak memiliki perbendaharaan yang cukup maka anak akan mengerti suatu ungkapan yang disampaikan oleh seseorang. Sebaliknya jika anak tidak memiliki banyak perbendaharaan kata atau kosakata maka anak akan kesulitan untuk berkomunikasi bahakan akan sulit memahami suatu ungkapan yang disampaikan oleh orang lain kepadanya. Walaupun elemen lain untuk berbicara telah terpenuhi, namun anak hanya sedikit memiliki perbendaharaan kata maka seorang anak akan kesulitan untuk berbicara (Zubaidah, 2004:462). Maka bahasa merupakan tonggak utama bagi seseorang untuk bisa berhubungan dengan orang lain. Perkembangan bahasa anak yang satu dan yang lain memiliki perbedaan, terdapat banyak faktor yang mempengaruhi perkembangan bahasa pada anak

Menurut (Jahja, 2011:56)
menyatakan berikut faktor yang mempengaruhi perkembangan bahasa anak salah satunya merupakan hubungan keluarga. Hubungan keluarga dapat diartikan sebagai sebuah proses dari kemahiran anak dalam berinteraksi dan berkomunikasi di dalam lingkungan keluarga. Terlebih pada saat orang tua membimbing anak serta memberikan contoh bagaimana cara penggunaan bahasa secara tepat. Hal ini didukung oleh (Putra et al., 2018:570) dalam penelitiannya pemberian stimulus dari orang tua benarbenar memiliki pengaruh penting terhadap perkembangan bahasa bagi anak. Apabila orang tua mengajak anak untuk berkomunikasi, maka semakin banyak pula perbendaharaan kata yang dimiliki oleh anak. Anak mulai mengerti bahwasanya komunikasi yang berarti tidak akan didapat apabila tidak memahami sesuatu yang disampaikan orang lain. Hal tersebut akan membawa anak semakin berusaha untuk mencapai perkembangan bahasa dalam dirinya.

Mengerti serta mengetahui perkembangan bahasa pada anak merupakan hal penting bagi orang tua, calon guru, khususnya guru di sekolah dalam memahami perkembangan bahasa pada anak tingkat sekolah dasar. Seperti yang diungkapkan oleh (Latifa, 2017:186) 
dalam penelitiannya, untuk memahami dan mengerti tentang aspek perkembangan bahasa anak merupakan suatu daya yang harus ada pada diri seorang pendidik.

Dengan adanya pengetahuan yang berhubungan dengan aspek perkembangan bahasa serta faktor yang dapat menjadi pengaruh dalam perkembangan bahasa pada anak khususnya pada tingkat sekolah dasar, guru dapat memfasilitasi perkembangan tersebut. Selain memfasilitasi guru dapat menangani berbagai permasalahan yang akan menghambat perkembangan bahasa pada anak.

Mengingat bagaimana pentingnya perkembangan bahasa pada anak tingkat sekolah dasar. Penting adanya kajian yang berkaitan dengan perkembangan bahasa. Adanya kajian ini diharapkan dapat berguna untuk orang tua, calon guru, serta guru di sekolah. Guru dapat menerapkan metode, materi, serta strategi pembelajaran serta dapat memfasilitasi perkembangan bahasa anak. Maka, peneliti berupaya untuk mengkaji lebih dalam Aspek Perkembangan Bahasa Pada Anak Tingkat Sekolah Dasar. Mengetahui aspek-aspek serta memahami faktor yang dapat mempengaruhi perkembangan bahasa pada anak merupakan tujuan utama dalam penelitian ini.

\section{METODE PENELITIAN}

Metode yang digunakan dalam penelitian ini adalah jenis metode penelitian studi pustaka (literatur) dilengkapi dengan pendekatan kualitatif. Penelitian studi pustaka adalah penelitian yang menggunakan berbagai macam literatur atau kepustakaan, baik berupa catatan, laporan hasil penelitian terdahulu, maupun buku-buku dari berbagai macam sumber (Hasan, 2004:5).

Pendekatan kualitatif pada penelitian penelitian ini adalah pendekatan berupa menu skrip, dokumen-dokumen dan hasil buah pikir dari peneliti terdahulu, dan penelitian kualitatif bersifat non angka. Dari berbagai macam data tersebut dapat dilihat dan dikategorikan kesesuaiannya berdasarkan pokok permasalahan yang sedang dikaji oleh peneliti.

Data primer merupakan data yang dikumpulkan atau diperoleh langsung oleh seseorang yang sedang melakukan penelitian atau orang yang bersangkutan yang membutuhkan suatu data. Data primer dapat disebut sebagai data baru atau asli (Hasan, 2004:14)

Karena penelitian menggunakan pendekatan kualitatif dengan metode studi pustaka, maka sumber primer yang dimaksud adalah buku yang berkaitan dengan perkembangan bahasa pada anak tingkat sekolah dasar.

Data sekunder dalam penelitian merupakan data yang didapat atau data yang telah dikumpulkan oleh orang yang telah melakukan penelitian dari berbagai sumber yang telah ada. Data sekunder diperoleh dari perpustakaan atau dari laporan penelitian terdahulu yang berkaitan dengan penelitian yang sedang dilakukan, (Hasan, 2004:19). Data sekunder yang dimaksud dalam penelitian ini adalah artikel, jurnal, serta laporan hasil penelitian terdahulu yang berkaitan dengan perkembangan bahasa pada anak tingkat sekolah dasar.

\section{HASIL DAN PEMBAHASAN}

Menurut (Kushartanti, Untung Yuwono, 2007:6) bahasa ialah suatu sistem tanda bunyi yang telah disepakati untuk digunakan oleh anggota kelompok masyarakat tertentu dalam mengidentifikasi diri, berkomunikasi serta bekerja sama. Bahasa digunakan untuk menyampaikan pesan, digunakan sebagai media untuk berkomunikasi dengan menggunakan simbol-simbol yang disepakati bersama, kemudian kata dirangkai berdasarkan urutan membentuk kalimat yang 
bermakna, dan mengikuti aturan atau tata bahasa yang berlaku dalam suatu komunitas atau masyarakat (Latifa, 2017:189).

Perkembangan bahasa anak dapat dilihat mengikuti usia. Ketika anak lahir dan menginjak masa sekolah perkembangan bahasa anak di mulai. Menurut (Usman, 2015:6) perkembangan bahasa anak usia dini terbagi ke dalam beberapa tahap diantaranya:

Pada saat anak berusia 0-1 tahun merupakan periode prelingual. Pada periode ini anak mulai menunjukkan ciri mengoceh atau berceloteh agar dapat berkomunikasi dengan orang tuanya. Namun, anak akan bersifat pasif pada saat orang tua memberikan stimulus pada anak, anak mengoceh sebagai bentuk komunikasi merupakan ciri utama, akan tetapi anak akan tetap memberikan respon yang berbeda terhadap stimulus yamh diberikan. Contoh: bayi akan tersenyum atau menunjukkan wajah bahagia pada seseorang yang dikenalnya, dan bayi akan menangis atau menunjukkan rasa takut pada orang yang tidak di kenalnya.

Pada saat anak berusia 1-2,5 tahun, maka periode lingual dimulai. Pada periode ini anak telah memiliki kemampuan untuk membuat satu atau beberapa kalimat pada saat anak berkomunikasi dengan orang lain.

Pada usia 2,5-5 tahun merupakan periode diferensiasi. Anak kemampuan bahasa anak telah sesuai dengan peraturan tata bahasa dan telah berkembang dengan baik baik dari segi kualitas maupun kuantitas.

Perkembangan bahasa pada anak tingkat Sekolah Dasar (SD) pada usia early primary year. Bahasa yang digunakan anak sudah berkembang hampir mencapai kesempurnaan. Menurut Ormrod dikutip oleh Surna, Nyoman dan Pandeirot (2014) dalam penelitian (Dewi et al., 2020:4) karakteristik perkembangan bahasa sekolah dasar dijabarkan sebagai berikut:

Anak telah menguasai sekitar 50.000 kata pada usia 6-8 tahun. Anak sudah memiliki kesadaran untuk menggunakan terminologi. Namun terkadang anak memiliki hambatan saat menggunakan kata hubung seperti jika, hanya, walaupun, tetapi, kecuali serta kata penghubung lainnya. Pada usia ini anak telah mengerti kalimat utuh bahkan yang memiliki banyak implikasi. Mulai berkembang kemampuan melakukan interpretasi, anak dapat mengetahi kata kerja serta bentuknya. Anak mulai mengerti jika terdapat kata-kata atau kalimat sindirian, pada masa ini anak mulai mampu untuk berkomunikasi dengan orang lain menggunakan kalimat yang panjang secara signifikan pengetahuan tentang dasar serta hakikat bahasa mulai berkembang walau masih bersifat abstrak. Contohnya kemampuan analisis anak tentang dasardasar perkembangan bahasa yang menjadi pengetahuan terstruktur dalam kognitif.

Anak memiliki perbendaharaan kata sebanyak 80.000 kata di usia 9-12 tahun, anak telah mengerti bagaimana menggunaka kosa kata yang memiliki hubungan dalam bidang akademik. Anak dapat menggunakan kata-kata yang sering digunakan pada saat pembelajaran sedang berlangsung. Anak mampu menggabungkan beberapa kata menjadi sebuah kalimat walaupun masih seperti instruksi. Dapat menggunakan kata sambung di dalam kalimat sesuai dengan aturan tata bahasa. Anak juga dapat memahami lambang bahasa seperti pantun, syair, peribahasa, metafora, serta hiperbola.

Berdasarkan teori di atas, dapat disimpulkan bahwa perkembangan bahasa anak ialah suatu yang mendasar berkaitan atau berhubungan dengan perkembangan fungsi otak anak, karena sesuatu yang diucapkan oleh anak berasal dari pemikiran anak itu sendiri.

Pada usia sekolah dasar perkembangan bahasa anak dapat dilihat dalam enam aspek diantaranya: kosakata, sintaksis, semantik, fonem, fonologi dan morfologi. Menurut (Oktadiana et al., 2019:230) berdasarkan hasil penelitiannya perkembangan bahasa anak akan selalu berkembang dalam lima aspek pada saat anak berada pada usia tingkat sekolah dasar, diantaranya: Fonetik merupakan salah satu aspek linguistik untuk mempelajari fonem. Fonem dapat diartikan sebagai dua kata yang memiliki bunyi yang berbeda secara fonetis berbeda walau dalam 
lingkungan yang sama, dan bunyi tersebut berpengaruh untuk membedakan arti dari kata-kata. Antara (l) dan (r) merupakan fonem yang berbeda pada bahasa Indonesia. Antara kata laga dan raga, lambat dan rambat, dan lain sebagainya, Morfologi dapat diartikan sebagai ilmu yang mempelajari tentang berbagai seluk beluk kata, perubahan bentuk dari suatu kata, serta perubahan suatu bentuk kata yang berkenaan dengan arti serta golongan dari kata tersebut. Perubahan kata baca menjadi kata membaca, dibaca, dibacakan, pembacaan, membacakan, dari satu kata dapat berubah menjadi kata yang berbeda dan dengan arti yang berbeda pula. Sintaksis dapat diiartikan sebagai ilmu bahasa yang mempelajari tentang tata cara pembuatan kalimat mulai dari prinsip hingga aturan-aturannya, sintaksis tersusun dari Subjek, Predikat, Objek dan Keterangan. Dalam penelitiannya, peneliti membentuk suatu kalimat "Sebastian mendorong sepeda" maka anak diminta untuk menunjukkan subjek, predikat dan objek dari kalimat tersebut. Semantik merupakan ilmu dalam suatu bahasa yang mempelajari arti serta makna yang terkandung di dalam bahasa. Misalnya anak diminta untuk mengartikan suatu kata seperti perempuan maka arti lainnya adalah wanita, dan kata banting tulang yang berarti bekerja keras. Pragmatik dapat disebut sebagai ilmu yang menghubungkan antara konteks serta makna dalam bahasa. Pragmatik membahas segala perihal yang berkaitan dengan penggunaan bahasa yang digunakan oleh manusia ditentukan oleh konteks Pragmatik mengikuti kondisi masyarakat dalam penggunaan bahasa diharuskan untuk menggunakan bahasa yang baik, sopan, santun pada situas-situasi yang telah di tentukan. Perkembangan leksikal atau kosakata berhubungan dengan kemampuan untuk menguasai dan menambah pengayaan kata-kata serta menambah pengetahuan yang berkaitan dengan kata-kata (Soetjiningsih, 2018:147).

Hasil dari pencapaian dari enam aspek perkembangan bahasa anak tingkat sekolah dasar tersebut adalah seluruh indikator perkembangan bahasa agar perkembangan bahasa anak dapat tercapai dengan baik. Pada aspek perkembangan pragmatik perkembangan anak masih cukup atau baru mulai berkembang. Hasil dari keseluruhannya aspek perkembangan bahasa anak sudah tercapai dengan sangat baik pada tingkat Sekolah Dasar (SD).

Perkembangan bahasa manusia telah lama di teliti oleh para psikolog. Perkembangan bahasa tidak terlepas dari berbagai macam teori psikologi. Terdapat tiga teori perkembangan bahasa pada anak diantaranya: teori nativis, behavioristik, dan kognitif.

Menurut (Desiani Natalina, 2019:22) Kaum behaviorisme menerangkan bahwasanya cara anak mendapatkan bahasa pertamanya tidak terlepas dari kendali dari luar (bukan dari dalam diri anak), rangsangan dari lingkungan sangat berperan penting pada saat anak memperoleh bahasanya. Kaum behaviorisme menyatakan kecakapan anak dalam berbicara dan menguasai suatu bahasa pada anak didapatkan dari rangsangan lingkungan. Perkembangan bahasa dapat dipandang sebagai perkembangan dari pengungkapan verbal baik berdasarkan secara acak hingga kemampuan yang baik untuk berkomunikasi dengan prinsip pertalian S-R atau Stimulus-Respon serta proses dari tiruan. Dikutip dari (Alfiana \& Kuntarto, 2020:2) B.F Skinner menyatakan bahwasanya metode pemerolehan bahasa pertama pada anak di dapat dari luar, melalui rangsangan lingkungan secara alamiah.

Berdasarkan teori nativisme pada saat anak mendapatkan bahasa pertama baik pada masa kanak-kanak kemampuan lingual anak perlahan membuka secara genetis. Pandangan nativisme bertolak dengan teori behaviorisme, lingkungan tidak memiliki pengaruh terhadap pemerolehan bahasa. Pemerolehan bahasa merupakan upaya biologis dari setiap individua tau dapat dikatakan sebagai "hipotesis pemberian alam". Ahli nativis beranggapan bahasa terlalu rumit serta kompleks hingga cukup mustahil jika di dapat dalam waktu yang singkat seperti peniruan (imitation). Maka, pasti terdapat beberapa aspek penting mengenai sistem tata bahasa yang telah dimiliki oleh 
manusia secara alamiah. Menurut Shafa, 2012 dalam (Yusuf, 2016:50) Chomsky merupakan ahli yang turut menganut aliran teori nativisme, ia menyatakan beberapa asumsi tentang manusia yang dapat menguasai bahasa verbal. Pertama, emampuan berbahasa merupakan genetis, memiliki pertambahan yang universal peran lingkungan hanya sedikit dalam kematangan berbahasa. Kedua, seseorang dapat memahami bahasa dalam tenggat waktu yang cukup singkat. Ketiga, pada lingkungan bahasa tidak mempunyai bahan yang cukup untuk tata bahasa orang dewasa yang terbilang rumit.

Teori kognitivisme berhubungan dengan mental dalam proses pemahaman tentang dunia sedikit banyaknya akan menghubungkan dengan pikiran ataupun berpikir. Maka kata kognisi dapat sinonimkan dengan kata pikiran atau berpikir. Menurut (Rizkiyana, 2019:19) Teori kognitif memberikan asumsi bahwa pemikiran memiliki kaitan antara bahasa serta hasil pengalaman dan juga intelektual. Sejalan dengan (Dewi et al., 2020:6) perkembangan bahasa anak dipengaruhi oleh peniruan yang berkaitan dengan orang dewasa saat berbicara.

Dapat disimpulkan, dari beberapa teori perkembangan bahasa pada anak. Lingkungan anak sangat mempengaruhi perkembangan bahasa anak. Anak cenderung mengikuti bahasa yang digunakan orang dewasa.

Menurut (Usman, 2015:19-22) terdapat dua belas faktor hambatan lainnya yang dapat mempengaruhi perkembangan bahasa pada anak, diantaranya: Sehat atau tidaknya anak memiliki pengaruh yang sangat penting bagi perkembangan bahasanya. Anak dengan fisik yang sehat akan lebih cepat untuk belajar berbicara, anak akan lebih bersemangat untuk menjadi anggota kelompok dan lebih termotivasi untuk bermain serta berkomunikasi dengan kelompoknya dibandingkan dengan anak yang memiliki kesehatan yang tidak begitu baik. Apabila anak mengalami sakit terusmenerus pada usia dua tahun, maka anak akan mengalami kesulitan atau kelambatan dalam perkembangan bahasa. Anak yang memiliki kecerdasan tinggi perkembangan bahasanya akan cepat dan dalam penguasaan bahasa akan lebih unggul dibandingkan anak yang memiliki tingkat kecerdasan rendah. Beberapa studi tentang sosial ekonomi dengan perkembangan bahasa menyatakan bahwa anak yang berasal dari keluarga kaya akan lebih cepat proses perkembangan bahasanya dibandingkan anak yang berasal dari keluarga miskin. Hal ini disebabkan karena bedanya kesempatan pendidikan yang di dapat oleh anak. Tidak terjadi perbedaan vokalisasi pada anak laki-laki dan anak perempuan di tahun pertama usia anak. Di usia ke dua tahun anak perempuan lebih unggul dalam perkembangan bahasa dibandingkan dengan anak laki-laki. Tata bahasa pada anak laki-laki kurang baik, dan memiliki kosa kata yang lebih sedikit, serta pengucapan kata tidak terlalu jelas di banding anak perempuan. Interaksi dan komunikasi yang dilakukan anggota keluarga dengan seorang anak sangat berpengaruh penting terhadap perkembangan bahasanya. Khususnya orang tua sebagai pendidik anak melatih dan memberikan contoh dalam menggunakan bahasa yang baik dan tepat Hubungan yang baik antara orang tua dan anak turut memfasilitasi perkembangan bahasa anak, sedangkan hubungan yang tidak baik turut berpengaruh, anak akan mengalami kesulitan atau kelambatan dalam perkembangan bahasanya. Huhungan yang baik antara orang tua dan anak menjadi peran penting, anak yang selalu di ajak berkomunikasi, diberikan perhatian dan kasih sayang akan lebih baik dan cepat perkembangan bahasanya dibandingkan dengan anak yang memiliki hubungan kurang baik terhadap orang tuanya. Anak yang jarang diajak berkomunikasi, tidak mendapat perhatian dan kasih sayang akan mengalami rasa takut dan cemas, gagap, serta mengalami hambatan, dalam perkembangan bahasanya. Anak yang memiliki keinginan untuk berinteraksi atau berkomunikasi dengan orang lain akan semakin banyak perbendaharaan kosa katanya. Anak akan semakin lancar berbicara. Semakin banyak dorongan atau motivasi dari orang tua kepada anak maka akan semakin baik kualitas anak dalam 
berbicara. Hal ini dapat dilakukan dengan mengajak anak untuk berkomunikasi, dan terus menanggapi apa yang dikatakan atau ditanyakan oleh anak. Jumlah dalam keluarga mempengaruhi perkembangan bahasa anak, anak tunggal akan lebih cepat dalam menguasai bahasa karena orang tua memiliki banyak waktu luang dengan anak dibandingkan dengan keluarga yang jumlahnya banyak. Anak yang lahir pertama perkembangan bahasanya akan lebih baik dari anak yang lahir pada urutan selanjutnya. Karena orang tua memiliki banyak waktu untuk mengajarkan dan memotivasi anak yang lahir pada urutan pertama. Anak yang dilatih dengan keras atau otoriter akan berdampak terhadap perkembangan bahasanya. Anak yang diberikan keleluasaan akan lebih termotivasi untuk belajar. Metode pelatihan orang tua terhadap anak merupakan hal penting. Pada umumnya anak yang dilahirkan kembar akan memiliki keterlambatan dalam perkembangan berbicara, karena anak hanya bermain dengan kembarnya dan anak hanya paham dengan logat khusus yang dimiliki. Tentu hal tersebut dapat melemahkan motivasi anak untuk berbicara dengan orang lain. Semakin banyak anak berhubungan dengan teman sebayanya makan semakin kuat pula motivasi anak untuk dapat berbicara dengan baik agar anak dapat diterima sebagai anggota kelompoknya.

\section{SIMPULAN}

Bahasa ialah suatu sistem tanda bunyi yang digunakan oleh seseorang untuk berkomunikasi dan untuk keperluan lainnya serta sebagai pengantar pendidikan. Sebagai makhluk sosial, manusia membutuhkan sarana untuk berinteraksi dan berkomunikasi. Begitu pula dengan anak tingkat sekolah dasar, perkembangan bahasa dalam diri anak sangat berpengaruh terhadap pengetahuan kemampuan dasar serta terhadap komunikasi timbal balik urutan kelahiran anak, lingkungan dan lain sebagainya. antara anak dan orang lain.

Perkembangan bahasa pada anak dimulai sejak prelingual dan terus berkembang mengikuti usia anak. Pada usia Pada usia tingkat sekolah dasar, perkembangan bahasa anak telah tercapai dengan sangat baik dan hampir sempurna. Baik dari segi aspek sintaksis, semantik, fonem, morfologi, progmatik, maupun kosakata atau leksikal.

\section{DAFTAR RUJUKAN}

Alfiana, R., \& Kuntarto, E. (2020). Perkembangan Bahasa Pada Anak Usia Dini. Repository Unja.

Desiani Natalina, G. G. (2019). Komunikasi Dalam Paud. Ksatria Siliwangi, Tasikmalaya.

Dewi, M. P., S, N., \& Irdamurni, I. (2020). Perkembangan Bahasa, Emosi, Dan Sosial Anak Usia Sekolah Dasar. Jurnal Ilmiah Pendidikan Dasar, 7(1).

Hasan, I. (2004). Analisis Data Penelitian Dengan Statistik. Bumi Aksara, Jakarta.

Jahja, Y. (2011). Psikologi Perkembangan.. Kencana, Jakarta.

Kushartanti, Untung Yuwono, M. R. L. (2007). Pesona bahasa: langkah awal memahami linguistik. PT. Gramedia Pustaka Utama, Jakarta.

Latifa, U. (2017). Aspek Perkembangan pada Anak Sekolah Dasar: Masalah dan Perkembangannya. Journal of Multidisciplinary Studies, 1(2).

Oktadiana, B., Hayati, E., \& Sofiana, I. A. (2019). Analisis Perkembangan Bahasa Anak Usia Dasar (Tercapai) Di Mi Ma'arif Sambego. Nazhruna: Jurnal Pendidikan Islam, 2(2).

Palupi, Y. (2015). Perkembangan Bahasa Pada Anak. Proseding Seminar Nasional PGSD UPY.

Putra, A. Y., Yudiemawati, A., \& Maemunah, N. (2018). Pengaruh Pemberian Stimulasi Oleh Orang Tua Terhadap Perkembangan Bahasa 
Anak Usia Toddler di PAUD Asparaga Malang. Journal Nursing News, 3(1).

Rizkiyana, M. (2019). Meningkatkan Perkembangan Bahasa Anak Usia Dini Melalui Media Kartu Bergambar Kelompok A Di Tk Aisyiah Bustanul Athfal Wates Gadingrejo Pringsewu. Skripsi. UIN Raden Intan Lampung

Soetjiningsih, C. H. (2018). Seri Psikologi Perkembangan: Perkembangan Anak Sejak Pembuahan Sampai dengan Kanak-Kanan Akhir. Kencana, Jakarta.

Susanto, A. (2011). Perkembangan Anak Usia Dini: pengantar dalam berbagai aspeknya. Kencana, Jakarta.
Usman, M. (2015). Perkembangan Bahasa dalam Bermain dan Permainan: : Untuk Pendidikan Anak. Deepublish, Yogyakarta.

Yusuf, E. B. (2016). Perkembangan dan Pemerolehan Bahasa Anak. Yin Yang: Jurnal Studi Islam, Gender Dan Anak, 11(01).

Zubaidah, E. (2004). Perkembangan Bahasa anak Usia Dini Dan Teknik Pengembangannya di Sekolah. Jurnal Cakrawala Pendidikan, (c). 